\title{
GARANTISTAS VS. ABOLICIONISTAS: AS CRÍTICAS DE FERRAJOLI AO ABOLICIONISMO PENAL E AS RÉPLICAS ABOLICIONISTAS AO GARANTISMO PENAL
}

Tatiana Badaró ${ }^{1}$

\begin{abstract}
Resumo
Apesar de inexistir total incompatibilidade entre garantismo e abolicionismo, o garantismo penal de Ferrajoli se afasta do pensamento abolicionista por assumir como premissa a possibilidade de resgatar a legitimidade do sistema penal. Este artigo analisa as críticas formuladas por Ferrajoli às propostas de abolição do modelo punitivo, sobretudo no que toca à necessidade do controle penal para minimizar violências formais e informais. A fim de contrapor esse raciocínio, são apresentadas as visões de quatro expoentes do abolicionismo penal: Hulsman, Christie, Mathiesen e Scheerer. As conclusões trazem uma síntese das respostas abolicionistas à defesa feita por Ferrajoli da manutenção da reação penal do Estado.
\end{abstract}

Palavras-chave: Garantismo; Abolicionismo; Ferrajoli; Hulsman; Sistema penal.

\section{INTRODUÇÃO}

O abolicionismo penal, corriqueiramente incluído dentre as correntes da criminologia crítica, é concebido, ao mesmo tempo, como uma tese, um modelo, um movimento, uma proposta e uma estratégia ${ }^{2}$. De maneira geral, os abolicionistas postulam a supressão de todo o sistema penal moderno, a fim de substitui-lo por um sistema alternativo de solução do conflito agressor-vítima ${ }^{3}$.

É comum que o abolicionismo seja colocado em oposição ao minimalismo. No entanto, o abolicionismo não é a antítese do minimalismo, uma vez que ambos perseguem a abolição ou minimização do poder punitivo estatal institucionalizado ${ }^{4}$. Para Scheerer, os minimalistas podem ser importantes aliados na realização dos objetivos de curto prazo do abolicionismo penal ${ }^{5}$. Dessa forma, a antítese tanto do abolicionismo

\footnotetext{
${ }^{1}$ Doutoranda em Direito na Universidade Federal de Minas Gerais. Professora universitária. E-mail: tatianambadaro@gmail.com

2 PIRES, Ariosvaldo de Campos; SALES, Sheila Jorge Selim de. Alguns movimentos político-criminais da atualidade. Revista Brasileira de Ciências Criminais, no 42, ano 11, jan.-mar., 2003, p. 303.

${ }^{3}$ PIRES, Ariosvaldo de Campos; SALES, Sheila Jorge Selim de. Alguns movimentos político-criminais da atualidade, p. 304.

${ }^{4}$ ANDRADE, Vera Regina Pereira de. Minimalismos, abolicionismos e eficienticismo: a crise do sistema penal entre a deslegitimação e a expansão. Revista Sequência. Florianópolis, nº 52, jul., 2006, p. 174

5 SCHEERER, Sebastian. Hacia el abolicionismo. In: HULSMAN, Louk; CHRISTIE, Nils; MATHIESEN, Thomas; SCHEERER, Sebastian; STEINERT, Heinz; DE FOLTER, Rolf. Abolicionismo penal. Trad. Mariano Alberto Ciafardini y Mirta Lilián Bondanza. Buenos Aires: Ediar Sociedad Anónima, 1989, p. 34.
} 
quanto do minimalismo é a máxima expansão e legitimação da intervenção penal promovida pelo discurso eficientista da "Lei e Ordem".

O garantismo penal de Ferrajoli se alia aos modelos minimalistas de Direito de penal, isto é, modelos orientados à limitação da violência punitiva e à máxima contração do sistema penal. Contudo, segundo Andrade, diferencia-se de outras perspectivas minimalistas por partir da deslegitimação do sistema penal, concebida como uma crise conjuntural e não estrutural de legitimidade, para a sua relegitimação ${ }^{7}$. Assim, diferentemente de Baratta $^{8}$ e Zaffaroni ${ }^{9}$, Ferrajoli toma o minimalismo com um fim em si mesmo e não como meio ${ }^{10}$.

Daí que, por assumir como premissa a absoluta necessidade de um mínimo de sistema penal, o pensamento de Ferrajoli contradiz alguns dos postulados fundamentais da perspectiva abolicionista. Diante disso, este artigo apresenta as críticas formuladas pelo professor italiano ao abolicionismo penal para, em seguida, indicar as respostas dadas por quatro expoentes abolicionistas (Hulsman, Christie, Mathiesen e Scheerer). As conclusões trazem uma síntese das réplicas abolicionistas à defesa feita por Ferrajoli da manutenção do controle penal do Estado.

\title{
O GARANTISMO PENAL TEM A PALAVRA: AS CRÍTICAS DE FERRAJOLI AO ABOLICIONISMO PENAL
}

Uma das perguntas filosóficas fundamentais postas por Ferrajoli em sua obra-prima "Direito e razão: teoria do garantismo penal" é: por que castigar? O abolicionismo penal se distingue de outras teorias jurídicopenais pela peculiaridade da resposta que fornece a essa pergunt ${ }^{11}$. O autor define como abolicionistas:

\begin{abstract}
"aquelas doutrinas axiológicas que impugnam como ilegítimo o direito penal, seja porque não admitem moralmente nenhum fim possível como justificador dos sofrimentos que ocasiona, seja porque consideram vantajosa a abolição da forma jurídico-penal da sanção punitiva e sua substituição por meios pedagógicos ou instrumentos de controle de tipo informal ou imediatamente social."12 (tradução nossa).
\end{abstract}

\footnotetext{
${ }^{6}$ ANDRADE, Vera Regina Pereira de. Minimalismos, abolicionismos e eficienticismo: a crise do sistema penal entre a deslegitimação e a expansão, p. 176.

7 ANDRADE, Vera Regina Pereira de. Minimalismos, abolicionismos e eficienticismo: a crise do sistema penal entre a deslegitimação e a expansão, p. 174 e 176.

${ }^{8}$ Cf. BARATTA, Alessandro. Criminologia crítica e crítica ao direito penal. Rio de Janeiro: Revan, 2002.

${ }^{9}$ Cf. ZAFFARONI, Eugenio Raúl. Em busca das penas perdidas. A perda de legitimidade do sistema penal. Rio de Janeiro: Revan, 1991.

${ }^{10}$ Outro defensor do direito penal mínimo que procura fornecer bases de legitimação para o direito penal é Hassemer, que entende que a formalização do controle social por meio do Direito penal é capaz de assegurar a sua limitação (HASSEMER, Winfried. Contra el abolicionismo: acerca de por qué no se debería suprimir el derecho penal. Revista de Derecho Penal, n. 2, 2007, p. 709729).

${ }^{11}$ FERRAJOLI, Luigi. Derecho y razón. Teoría del garantismo penal. Trad. Andrés Ibáñez, Alfonso Ruiz Miguel, Juan Carlos Bayón Mohino, Juan Terradillos Basoco e Rocío Cantarero Bandrés. 5a ed. Madrid: Trotta, 2001, p. 247.

${ }^{12}$ No original: "Considero abolicionistas sólo aquellas doctrinas axiológicas que impugnan como ilegítimo el derecho penal, bien porque no admiten moralmente ningún posible fin como justificador de los sufimientos (sic) que ocasiona, bien porque
} 
Segundo Ferrajoli, o direito penal é o único ramo jurídico que realiza essa autocrítica, motivo pelo qual não existem doutrinas abolicionistas do direito civil, comercial, constitucional, administrativo, etc. Apesar disso, o problema da legitimidade política e moral do direito penal é também, em grande medida, um problema da legitimidade do Estado como monopólio organizado da força. ${ }^{13}$

O garantismo penal de Ferrajoli se contrapõe ao abolicionismo pelo fato de atribuir maior relevo aos "custos potenciais de uma anarquia punitiva" do que aos custos atuais e reais do sistema penal. Para o autor italiano, "o Direito penal mínimo estaria legitimado pela necessidade de proteger, a um só tempo, as garantias dos 'desviantes' e 'não desviantes"'14. Por isso, ele defende a pena jurídica como método institucional de minimização da reação violenta ao desvio e garantia do acusado frente às arbitrariedades, os excessos e os erros do sistema jurídico de controle social ${ }^{15}$.

Assim, as doutrinas abolicionistas são criticadas por ignorarem a importância das garantias do direito penal como técnica de regulação e delimitação da violência punitiva, incorrendo no equívoco de rechaçar, indistintamente, modelos penais autoritários e liberais. Ao desprezar o enfoque garantista do direito penal, o abolicionismo renuncia a oferecer qualquer contribuição ao problema da limitação e controle do poder punitivo. ${ }^{16}$

O radicalismo da concepção abolicionista, na visão de Ferrajoli, consubstancia-se nas seguintes propostas: 1) "improváveis projetos de microcosmos sociais baseados na solidariedade e na fraternidade"; 2) "vagos objetivos de 'reapropriação social' dos conflitos" por ofendidos e ofensores e 3) "métodos primitivos de composição patrimonial das ofensas que recordam as antigas formas de vingança de sangue". ${ }^{17}$

Segundo o autor, o modelo de autorregulação social espontânea, proposto pelas doutrinas abolicionistas, é pensado para uma sociedade perfeita e utópica e, portanto, carente de embasamento científico ${ }^{18}$. Além disso, tal proposta é inspirada por um moralismo mitológico e nostálgico em relação a modelos arcaicos e tradicionais de “comunidades sem direito", não apresentando nada de original que já não tenha sido projetado pela ideologia anarquista $^{19}$.

Ferrajoli afirma que o abolicionismo penal acaba por perseguir dois modelos distintos e opostos de sociedade, ambos escassamente atrativos: 1) a sociedade selvagem, belicista, desordeira e abandonada à lei do mais forte e 2) a sociedade disciplinária, pacificada e totalizante, na qual os conflitos são controlados a partir de

\footnotetext{
consideran ventajosa la abolición de la forma jurídico-penal de la sanción punitiva y su sustitución por medios pedagógicos o instrumentos de control de tipo informal e inmediatamente social." (FERRAJOLI, Luigi. Derecho y razón, p. 248).

${ }^{13}$ FERRAJOLI, Luigi. Derecho y razón, p. 248.

${ }^{14}$ ANDRADE, Vera Regina Pereira de. Minimalismos, abolicionismos e eficienticismo, p. 176.

${ }^{15}$ FERRAJOLI, Luigi. Derecho y razón, p. 248-249.

${ }^{16}$ FERRAJOLI, Luigi. Derecho y razón, p. 251.

${ }^{17}$ FERRAJOLI, Luigi. Derecho y razón, p. 251.

${ }^{18}$ FERRAJOLI, Luigi. Derecho y razón, p. 329.

${ }^{19}$ FERRAJOLI, Luigi. Derecho y razón, p. 250-251.
} 
mecanismos ético-pedagógicos de interiorização da obediência à ordem, tratamentos médico-terapêuticos e vigilância social difusa. Daí a inconsistência lógica e axiológica das premissas do abolicionismo penal, que servem a fundamentar sistemas ilimitadamente autoritários e à mercê do jogo desenfreado dos poderes. ${ }^{20}$

O professor italiano afirma que, como consequência desses dois modelos de sociedade, o abolicionismo penal oferece quatro modelos alternativos de controle social: 1) social-selvagem: presente historicamente em ordenamentos arcaicos nos quais a pena pública dava lugar à vingança individual ou parental, à vingança de sangue, às represálias, ao duelo etc., sendo os "custos" suportados pela parte mais fraca; 2) estatal-selvagem: próprio de ordenamentos despóticos e autoritários, antigos ou modernos, nos quais a pena pública é imposta arbitrariamente e sem garantias; 3) social-disciplinário: realizado em comunidades primitivas autorreguladas, fortemente moralizantes e ideologizantes, por meio da autocensura, policiamento moral, panóptico social, pressão da opinião pública, ostracismo e linchamentos públicos; 4) estatal-disciplinário: tipicamente moderno, no qual a função preventiva de segurança pública é exercida por métodos de vigilância total, como espionagem de cidadãos por polícias secretas, obtenção e armazenamento técnico-científicos de informações privadas, monitoramento audiovisual etc. $^{21}$

Não obstante as críticas, Ferrajoli reconhece que o pensamento abolicionista é importante por dois motivos. Em primeiro lugar, o abolicionismo tem o mérito de favorecer a autonomia da criminologia crítica, suscitando investigações sobre as origens culturais e sociais do desvio e a relatividade histórica e política dos interesses penalmente protegidos. Ademais, por questionar a latente legitimidade moral das doutrinas penais dominantes e denunciar as arbitrariedades, os custos e os sofrimentos provocados pelo sistema penal, os abolicionistas impõem uma pesada carga de justificação aos que defendem a sua manutenção. ${ }^{22}$

Com efeito, Ferrajoli concorda com várias das críticas feitas pelo abolicionismo ao sistema penal. $\mathrm{O}$ autor defende, por exemplo, a redução da pena de prisão a um patamar máximo de 10 anos e, em longo prazo, a sua eliminação. Sustenta, ainda, a descriminalização de uma série de condutas, tais como as contravenções, os crimes punidos com pena de multa, as meras imoralidades, os crimes de perigo abstrato ou presumido e alguns crimes contra o patrimônio. No entanto, assevera que, mesmo em uma sociedade idealmente perfeita, o direito penal não deveria desaparecer completamente. ${ }^{23}$

Para Ferrajoli, o garantismo responde às críticas do abolicionismo e resolve o problema da legitimidade do sistema penal. Nessa perspectiva, o direito penal garantista é a via que permite reduzir a violência na sociedade, uma vez que os males provenientes da imposição da pena são menores dos que os decorreriam dos crimes

\footnotetext{
${ }^{20}$ FERRAJOLI, Luigi. Derecho y razón, p. 251-252.

${ }^{21}$ FERRAJOLI, Luigi. Derecho y razón, p. 338.

${ }^{22}$ FERRAJOLI, Luigi. Derecho y razón, p. 252.

${ }^{23}$ FERRAJOLI, Luigi. Derecho y razón, passim.
} 
prevenidos, das vinganças privadas e dos castigos informais e arbitrários. ${ }^{24}$

Portanto, ao negar as teorias tradicionais da pena (retributivista e preventivas), Ferrajoli reconstrói a teoria da prevenção geral negativa, derivada da teoria da coação psicológica de Feuerbach, a partir de um utilitarismo que visa maximizar os direitos humanos dos "sujeitos mais vulneráveis e débeis do evento violento e do teatro processual: a vítima no momento do crime, o réu durante o processo e o condenado na execução da pena”25.

\section{COM A PALAVRA, OS ABOLICIONISTAS}

A denominação "abolicionismo penal", emprestada da luta histórica contra a escravidão e a pena de morte, designa a proposta mais radical de destruição do sistema penal e da própria lógica punitiva. Conforme explica Pavarini, o abolicionismo radical congrega objetivos parciais de eliminação do cárcere e dos manicômios (abolicionismo institucional) e de drástica redução da intervenção penal (minimalismo penal) ${ }^{26}$.

No começo da década de 1970, o holandês Hermann Bianchi afirmava que se deveria abolir a ideia de castigo como forma aceitável de reagir ao delito. A pena seria substituída por um sistema de justiça que protegesse o estigmatizado e lhe oferecesse oportunidades de sentir e demonstrar remorso, proporcionando a reconciliação e a pacificação. ${ }^{27}$

Por isso, Passetti destaca que "O abolicionismo é mais do que a abolição do direito penal ou da prisão moderna", na medida em que "problematiza a sociabilidade autoritária que funda e atravessa o Ocidente como pedagogia do castigo em que, sob diversas conformações históricas, atribui-se a um superior o mando sobre o

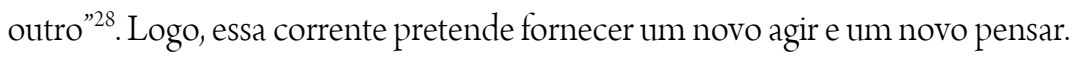

Observa-se que o abolicionismo penal aparece, simultaneamente, como movimento social e perspectiva teórica. Por um lado, seus líderes fundaram organizações voltadas à reforma do sistema penal, como é o caso da associação norueguesa KROM, fundada por Mathiesen em 1969. Por outro lado, as diferentes variantes abolicionistas se filiam a diferentes linhas teóricas: estruturalismo (Foucault), materialismo e marxismo (Mathiesen), fenomenologia (Hulsman e Christie) etc. ${ }^{29}$

Scheerer se refere ao abolicionismo como uma "teoria sensibilizadora", isto é, uma teoria que tem como

\footnotetext{
${ }^{24}$ FERRAJOLI, Luigi. Derecho y razón, p. 337.

${ }^{25}$ CARVALHO. Salo de. Antimanual de Criminologia. 5a ed. São Paulo: Saraiva, 2013, p. 234.

${ }^{26}$ PAVARINI, Massimo. El sistema de derecho penal entre abolicionismo y reduccionismo. Trad. J. L. Domínguez y R. Bergalli. Poder y control. Revista hispano-latinoamericana de disciplinas sobre el control social, no 1, 1987, p. 141-142.

${ }^{27}$ ANITUA, Gabriel Ignacio. Histórias dos pensamentos criminológicos. Trad. Sérgio Lamarão. $1^{a}$ ed. Rio de Janeiro, Revan, 2008, p. 696-697 e 702 .

${ }^{28}$ PASSETTI, Edson. A atualidade do abolicionismo penal. In: PASSETTI, Edson (org.). Curso livre de abolicionismo penal. 2a ed. Rio de Janeiro: Revan, 2012, p. 16.

${ }^{29}$ ANDRADE, Vera Regina Pereira de. Minimalismos, abolicionismos e eficienticismo, p. 165-167.
} 
objetivo "transcender modelos, classificações e presunções tradicionais, mas sem apresentar provas acabadas dessas novas ideias nem o inventário de suas próprias ferramentas conceituais e metodológicas" ${ }^{30}$. Ainda que não configure um salto revolucionário na evolução científica nem o presságio do fim de uma ciência e o surgimento de outra totalmente nova, o abolicionismo é um novo paradigma capaz de criar uma crise ao desestabilizar crenças quase axiomáticas na relação culpa-castigo.

Nesse sentido, a defesa da abolição do sistema repressivo é feita com base nos seus evidentes efeitos contraprodutivos em relação aos seus objetivos declarados, uma vez que a pena não compre as funções de ressocialização e prevenção que the são atribuídas pelo discurso legitimador nem atende às verdadeiras necessidades dos envolvidos no conflito. As principais razões que tornam problemático o controle social por meio da justiça penal podem ser assim sintetizadas: 1) causa sofrimento desnecessário e distribuído de modo injusto e desigual na sociedade; 2) expropria o conflito dos sujeitos nele diretamente envolvidos sem produzir qualquer efeito positivo para eles e 3 ) tende a abusos e excessos, sendo sumamente difícil de ser mantido sob controle. ${ }^{31}$

Com efeito, é possível dizer que o abolicionismo é uma bandeira sob a qual navegam diferentes barcos ${ }^{32}$. Assim, nota-se a diversidade das vertentes abolicionistas, que vão desde a matriz anarquista de Max $\operatorname{Stirner}^{33}$ até o abolicionismo negro e feminista de Angela Davis ${ }^{34}$. Considerando os limites do presente trabalho, analisaremos os diagnósticos e as propostas abolicionistas de apenas quatro dos seus mais tradicionais representantes: Hulsman, Christie, Mathiesen e Scheerer.

\section{Louk Hulsman}

Louk Hulsman, que em 1964 se tornaria professor de direito penal na Universidade de Rotterdam, foi preso pela polícia colaboracionista holandesa em 1944 e enviado para um campo de concentração na Alemanha nazista. Após conseguir fugir, regressou a seu país de origem e se juntou à resistência. Conforme o próprio Hulsman reconheceria anos mais tarde, a experiência com a ocupação alemã, a resistência e a Segunda Guerra Mundial o levaram a desmistificar a figura do Estado: "Um ceticismo profundo iria tomar conta de mim, finalmente me impedindo de admitir qualquer sistema acabado de explicações gerais, que não pudesse ser

\footnotetext{
${ }^{30}$ SCHEERER, Sebastian. Hacia el abolicionismo, p. 21.

${ }^{31}$ DE FOLTER, Rolf. Sobre la fundamentación metodológica del enfoque abolicionista del sistema de justicia penal. Una comparación de las ideas de Hulsman, Mathiesen y Foucalt. In: HULSMAN, Louk; CHRISTIE, Nils; MATHIESEN, Thomas; SCHEERER, Sebastian; STEINERT, Heinz; DE FOLTER, Rolf. Abolicionismo penal, p. 61; ANDRADE, Vera Regina Pereira de. Minimalismos, abolicionismos e eficienticismo, p. 172.

${ }^{32}$ DE FOLTER, Rolf. Sobre la fundamentación metodológica del enfoque abolicionista del sistema de justicia penal, p. 59.

${ }^{33}$ Para uma crítica dessa corrente: FERRAJOLI, Luigi. Derecho y razón, p. 249.

${ }^{34}$ Cf. DAVIS, Angela Y. Are prisons obsolete? New York: Seven Stories Press, 2003.
} 
verificado"35.

Esse ceticismo colocaria em xeque a justiça e a conveniência do sistema penal. $\mathrm{O}$ autor questiona a afirmação de que a eliminação do sistema penal implicaria na multiplicação dos atos violentos, tendo em vista que jamais foi cientificamente demonstrado que tal sistema concede proteção eficaz contra a violência nem que seja $\mathrm{o}$ único mecanismo capaz de garantir essa proteção ${ }^{36}$.

Os anos de observação e pesquisa levaram Hulsman a concluir que noções abstratas e redutoras como "crime" e "delito" limitam as possibilidades de compreensão dos conflitos sociais, bem como sufocam as diversas respostas que nascem naturalmente dos indivíduos sem a intervenção da estrutura estatal. $\mathrm{O}$ autor identifica cinco diferentes formas de reação a um evento problemático: punitiva, compensatória, terapêutica, conciliadora e educativa. Para ele, o discurso jurídico-penal exclui de antemão as medidas de controle social não punitivas. ${ }^{37}$

De fato, a punição é uma forma de interação humana presente em diversas práticas sociais, inclusive no âmbito da família, escola, trabalho, esporte etc., as quais permitem aos sujeitos conhecer, a partir de suas experiências diretas, tanto o punir quanto o ser punido. Contudo, essas experiências punitivas não coincidem com os processos punitivos desenvolvidos no interior da justiça criminal, uma vez que, nos castigos impostos profissionalmente pelo sistema, inexiste a relação entre aquele que pune e aquele que é punido. Diante disso, Hulsman afirma que o sistema penal "usa a linguagem da punição de modo a esconder os reais processos em curso e produzir consenso através de sua errônea apresentação, assimilando-os aos processos conhecidos e aceitos pelo público"38.

Segundo Hulsman, os eventos definidos como crime não diferem de maneira substancial, ontológica ou intrínseca dos eventos não definidos. Da mesma forma, os sujeitos considerados "criminosos" não constituem uma categoria "especial" de pessoas. Representam, na realidade, apenas uma pequena parcela dos sujeitos implicados na prática de fatos definidos como crime, em sua maioria homens jovens provenientes dos setores sociais mais desfavorecidos. ${ }^{39}$

O conceito de criminalidade abarca as situações mais variadas: violência familiar, roubo, contrabando,

\footnotetext{
${ }^{35}$ CELIS, Jacqueline Bernat de Celis; HULSMAN, Louk. Conversas com um abolicionista do sistema penal. In: HULSMAN, Louk. Penas perdidas: o sistema penal em questão. Trad. Maria Lúcia Karam. Rio de Janeiro: Luam Editora, 1993, p. 23.

${ }^{36}$ HULSMAN, Louk. Penas perdidas: o sistema penal em questão, p. 107-108.

${ }^{37}$ HULSMAN, Louk. Penas perdidas: o sistema penal em questão, p. 99-100. O autor destaca que, mesmo nos casos em que a justiça penal recorre à "negociação", essa "no se da entre las parte implicadas en el 'hecho original' sino entre profesionales a los que les interesa fundamentalmente su trabajo cotidiano en la justicia penal” (HULSMAN, Louk. La criminología crítica y el concepto de delito. In: HULSMAN, Louk; CHRISTIE, Nils; MATHIESEN, Thomas; SCHEERER, Sebastian; STEINERT, Heinz; DE FOLTER, Rolf. Abolicionismo penal, p. 98).

${ }^{38}$ HULSMAN, Louk. Alternativas à justiça criminal. In: PASSETTI, Edson (org.). Curso livre de abolicionismo penal, p. 35-36. No mesmo sentido, Cf. HULSMAN, Louk. Penas perdidas: o sistema penal em questão, p. 76-77. Essa diferença entre o controle social informal ou difuso e o controle social formal ou estatal passa despercebida por Hassemer, em: HASSEMER, Winfried. Contra el abolicionismo: acerca de por qué no se debería suprimir el derecho penal, p. 711-712.
} 
infrações de trânsito, poluição ambiental, corrupção etc. Tais fatos não se identificam sequer pela suposta gravidade, pois inúmeros problemas individuais e sociais sérios não são tratados como criminosos: dificuldades conjugais e entre pais e filhos, desemprego, falta de habitação etc. A escala hierárquica de gravidade é estabelecida tendo em vista apenas os fatos que estão dentro do sistema, sem qualquer comparação com os fatos que se situam foram dele. ${ }^{40}$

A justiça criminal reconstrói a realidade a partir de um único episódio, delimitado no tempo e no espaço, cuja culpa pela ocorrência será atribuída, artificialmente, ao indivíduo isolado ${ }^{41}$. Por outro lado, algumas das pessoas atingidas pelos fatos são identificadas como vítimas e separadas dos ditos "perpetradores". Passam, assim, a ocupar uma posição extremamente débil, na qual se tornam um "instrumento" despido de vontade e perspectiva próprias, destinado a garantir o êxito do procedimento legal. ${ }^{42} \mathrm{Na}$ visão de Hulsman, "a organização cultural da justiça criminal cria 'indivíduos fictícios' e uma interação 'fictícia' entre eles” ${ }^{43}$.

Além disso, o sistema penal "rouba" o conflito das pessoas nele diretamente envolvidas. A vítima não tem a oportunidade de compreender e assimilar o que realmente se passou nem de participar da construção da resposta institucional, não lhes sendo dadas condições de dimensionar ou opinar sobre as consequências reais às quais estará submetido o condenado. O sistema penal se apropria de tal forma do "assunto", congelando-o no tempo e ignorando o caráter evolutivo das experiências humano, que o fato levado a julgamento nada mais tem a ver com o fato vivenciado. Por isso, Hulsman diz que "o sistema penal trata de problemas que não existem".44

Crimes e criminosos não constituem um fato natural e estabelecido, mas são resultado de uma escolha humana modificável: “Um belo dia, o poder político para de caçar as bruxas e aí não existem mais bruxas”. Dessa maneira, "De um dia para o outro, o que era delito deixa de sê-lo e aquele que era considerado delinquente se torna um homem honesto ou, pelo menos, não tem mais que prestar contas à justiça penal”. Por certo, ressalta

\footnotetext{
${ }^{39}$ HULSMAN, Louk. Alternativas à justiça criminal, p. 43. Também em: HULSMAN, Louk. La criminología crítica y el concepto de delito, p. 87 e 90-91.

${ }^{40}$ HULSMAN, Louk. Alternativas à justiça criminal, p. 43 e 46.

${ }^{41}$ Segundo Hulsman, "o sistema penal fabrica culpados, na medida e que seu funcionamento mesmo se apoia na afirmação da culpabilidade de um dos protagonistas, pouco importando a compreensão e a vivência que os interessados tenham da situação” (HULSMAN, Louk. Penas perdidas: o sistema penal em questão, p. 67).

${ }^{42}$ HULSMAN, Louk. Alternativas à justiça criminal, p. 45-47.

${ }^{43}$ HULSMAN, Louk. Alternativas à justiça criminal, p. 45.

${ }^{44}$ HULSMAN, Louk. Penas perdidas: o sistema penal em questão, p. 82-83. Nessa linha: "A intervenção estereotipada do sistema penal age tanto sobre a 'vítima', como sobre o 'delinquente'. Todos são tratados da mesma maneira. Supõe-se que todas as vítimas têm as mesmas reações, as mesmas necessidades. O sistema não leva em conta as pessoas em sua singularidade. Operando em abstrato, causa danos inclusive àqueles que diz querer proteger". (HULSMAN, Louk. Penas perdidas: o sistema penal em questão, p. 83-84). O autor ressalta que o caráter fechado e inflexível do sistema penal é um fato que agrava o efeito alienante da intervenção penal: “(...) la interpretación de la realidad según la justicia penal prácticamente no podrá coincidir nunca con las dinámicas de interpretación de la realidad de aquellos que están directamente involucrados. En la justicia penal generalmente se toman decisiones sobre una realidad existente sólo dentro del sistema y que rara vez encuentra su contrapartida en el mundo exterior". (HULSMAN, Louk. La criminología critica y el concepto de delito, p. 104).
} 
Huslman, a lei cria tanto o crime quanto o criminoso. ${ }^{45}$

Daí que o fato de ser um evento criminalizável não é, necessariamente, indicativo do nível de vitimização, porquanto existem eventos não criminalizáveis que geram mais problemas e sofrimentos para as suas vítimas do que outros criminalizáveis. Por isso, "buscar alternativas à justiça criminal significa, em primeiro lugar, buscar definições alternativas de fatos que podem provocar processos de criminalização”. Afinal, como nenhum fato pode ser universalmente definido como algo ruim, não se pode dizer que a pretensão de prevenir o crime seja sempre algo bom e desejável para a sociedade. ${ }^{46}$

Por outro lado, a organização social da justiça criminal se caracteriza pela radical divisão de tarefas, a qual impossibilita que os funcionários regulem a sua própria atividade conforme as circunstâncias concretas. Impede, ainda, que os servidores técnico-burocratas do sistema penal assumam alguma responsabilidade pessoal por suas atividades, uma vez que o discurso de responsabilização dos "transgressores" não permite pensar na responsabilidade dos que atuam neste modelo de controle social. ${ }^{47}$

Estruturado dessa maneira, o sistema penal estatal dificilmente pode alcançar objetivos como "combater a criminalidade" e "prestar justiça". Como todas as grandes burocracias, sua tendência principal não se dirige para objetivos externos e sim internos, tais como diminuir suas dificuldades, crescer, velar pelo bem-estar de seus membros e assegurar a própria sobrevivência. Para Hulsman, "O processo da burocratização e profissionalização, que transpassa o sistema penal, faz dele um mecanismo sem alma". ${ }^{48}$

As cifras negras, isto é, a diferença entre os fatos criminosos praticados e os perseguidos pelas autoridades demonstram que a efetiva criminalização é um fato raro e excepcional ${ }^{49}$. Todavia, não significa que esses eventos não estejam sendo "tratados", quotidianamente, de alguma forma fora da justiça criminal, sobretudo em esferas não legais como família, escola, organizações profissionais, instituições religiosas, associações de bairro, círculo de amigos, entre outros ${ }^{50}$.

Por isso, o autor discorda da afirmação de que o desaparecimento do sistema penal levaria ao

\footnotetext{
${ }^{45}$ HULSMAN, Louk. Penas perdidas: o sistema penal em questão, p. 64.

${ }^{46}$ HULSMAN, Louk. Alternativas à justiça criminal, p. 52-54; HULSMAN, Louk. Penas perdidas: o sistema penal em questão, p. 139.

${ }^{47}$ HULSMAN, Louk. Alternativas à justiça criminal, p. 47.

${ }^{48}$ HULSMAN, Louk. Penas perdidas: o sistema penal em questão, p. 66. Ver também: HULSMAN, Louk. La criminología crítica y el concepto de delito, p. 88.

49 "Apesar de altamente custosa do ponto de vista humano e social, a intervenção penal na vida social é marginal e estatisticamente desprezível” (HULSMAN, Louk. Penas perdidas: o sistema penal em questão, p. 66).

${ }^{50}$ HULSMAN, Louk. Alternativas à justiça criminal, p. 44, 48-50. O autor cita três experiências reais: 1) o caso de um furto à residência de sua família, no qual a reparação foi conduzida por ele, sua esposa, os jovens que praticaram o fato e suas famílias; 2) casos de utilização na Holanda de procedimentos civis sumários por mulheres vítimas de violência sexual, como uma forma rápida, econômica e empoderadora de as vítimas reivindicarem demandas específicas e 3) pesquisa em um bairro de uma cidade holandesa média que indicou que, conforme se promoveu uma reorganização social que aproximou os diferentes estilos de vida dos habitantes, os conflitos intragrupos e entre grupos diversos passaram a ser enfrentados sozinhos, de modo positivo e civilizado, sem recorrer a pretensões criminalizantes.
} 
ressurgimento da vingança privada. Em primeiro lugar, porque a autodefesa punitiva já está presente em contextos em que o sistema penal funciona a todo vapor e não há motivo para acreditar que tal fenômeno se agravaria. Em segundo lugar, porque as vítimas, em geral, desejam ser ajudadas e protegidas de maneira eficiente e não necessariamente que haja punições. Conforme argumenta Hulsman, mesmo naqueles casos em que as vítimas reivindicam punição, elas o fazem temporariamente e contaminadas pelo discurso oficial que o próprio sistema penal dissemina na sociedade. ${ }^{51}$

O professor holandês via as justificativas de um sistema penal liberal e humanista como utopias negadoras da realidade social, uma contradição em termos. Embora não recusasse e sim defendesse as garantias penais, Hulsman criticava o "edifício legitimador de palavras do sistema punitivo representado pela Universidade", propondo o abandono desse saber técnico-jurídico a fim de construir, com otimismo político, alternativas a partir de pressupostos teológicos (recusa ao castigo), antropológicos (resolução humana do conflito) e sociológicos (crítica ao sistema penal).52

Conforme assinala Anitua, "é possível deslegitimar como falsa a imputação feita aos abolicionistas em geral, e a Hulsman em particular, de pleitear 'utopias' e esquecer os que realmente sofrem ou esquecer a realidade dos 'delitos" ${ }^{53}$. Aliás, Hulsman estava muito atento ao sofrimento dos seus semelhantes e acreditava que a abolição do sistema penal reduziria tal sofrimento.

Em razão disso, a abolição de todo o sistema penal não seria uma utopia, mas uma necessidade lógica, um diagnóstico realista e uma demanda de justiça. Nesse quadro, Hulsman reclama a abolição da administração estatal centralizada da justiça penal em sua totalidade, que deveria ser substituída por formas descentralizadas de regulação autônoma de conflitos, nas quais aqueles que estão diretamente envolvidos na situação-problema teriam mais influência. Com isso, ele não pretende substituir a pena por estruturas de tratamento médico e pedagógico, mas abolir o nível estatal de regulação de conflitos em favor de um nível direto ou mais autônomo. ${ }^{54}$

Em síntese, são algumas das propostas apresentadas por Hulsman:

a) Abandono do dialeto penal: Para superar a lógica do sistema penal, é preciso mudar a linguagem e rejeitar o dialeto penal (crime, criminoso, criminalidade etc.). Um novo vocabulário afastaria uma visão estigmatizante sobre as pessoas e situações e facilitaria o surgimento de novas formas de enfrentar os problemas. Assim, devem ser abolidos conceitos como "gravidade", "periculosidade" e "culpabilidade", bem como a dicotomia entre bem e

\footnotetext{
${ }^{51}$ HULSMAN, Louk. Penas perdidas: o sistema penal em questão, p. 114-115.

${ }^{52}$ ANITUA, Gabriel Ignacio. Histórias dos pensamentos criminológicos, p. 697 e 701.

${ }^{53}$ ANITUA, Gabriel Ignacio. Histórias dos pensamentos criminológicos, p. 697.

${ }^{54}$ DE FOLTER, Rolf. Sobre la fundamentación metodológica del enfoque abolicionista del sistema de justicia penal, p. 58. Hulsman assinala que uma coisa é suprimir a mecânica penal e outra coisa é excluir toda e qualquer coerção. Mesmo com a abolição do sistema penal, continuaria a ser dada à polícia, por exemplo, a possibilidade de prender um indivíduo para impedir que ele continue a atacar outro. No entanto, esse poder de coerção deve ser mantido sob o mais rigoroso controle judiciário. (HULSMAN, Louk. Penas perdidas: o sistema penal em questão, p. 113).
} 
mal. ${ }^{55}$

b) Abolição da prisão: $\mathrm{O}$ abolicionismo penal de Hulsman é um abolicionismo de todo o sistema penal e não apenas da prisão. No entanto, abolir a prisão imediatamente é uma parte importante da sua proposta. $\mathrm{O}$ autor considera o encarceramento, cujos inúmeros males são por ele destacados, a "pena perdida" por excelência: um sofrimento não criativo, desprovido de sentido, verdadeiro nonsense. A prisão despersonaliza e dessocializa os homens. ${ }^{56}$

c) Devolução do conflito aos envolvidos e adequação da reação ao caso concreto: É preciso orientar o enfoque às pessoas e grupos que vivem diretamente o conflito, abandonando-se a predefinição uniforme e em abstrato dos caminhos a serem obrigatoriamente seguidos. A determinação dos mecanismos de definição e reação aplicáveis a cada situação-problema (compensatório, conciliatório, terapêutico, educativo etc.) deve sempre estar ligada ao caso concreto e variar de acordo com o caráter único de cada situação-problema. Há também que se admitir que, independentemente do que se decida fazer ou não, determinados problemas não serão solucionados. ${ }^{57}$

Com a abolição do sistema penal, a resolução de conflitos seria repensada numa nova linguagem, retomada por outra lógica e transformada desde seu interior. Daí decorreria a revitalização do tecido social a partir da promoção de práticas mais solidárias de organização social. Essa renovação não eliminaria as situações problemáticas, mas o fim das soluções redutoras e estereotipadas, impostas de cima para baixo, permitiria que irrompessem novos e variados enfoques que, hoje, mal conseguimos imaginar. ${ }^{58}$

\section{Nils Christie}

Na década de 1950, o criminólogo norueguês Nils Christie, professor na Universidade de Oslo, dedicouse a criticar a ideologia do tratamento presente no sistema carcerário do Estado do bem-estar social, responsável pelo prolongamento indefinido do castigo ${ }^{59}$. O autor observou que: 1) os centros de tratamento são idênticos ou muito similares aos cárceres comuns; 2) os métodos científicos não impedem a reincidência e 3) conceitos clínicos como periculosidade são absolutamente vazios ${ }^{60}$.

Para o autor, a pena é um mal, uma imposição deliberada de sofrimento, e precisa ser restringida por não ser a melhor opção de controle social. A fim de causar dor, a pena de prisão retira o tempo daqueles que não possuem outros bens com os quais compensar o crime. Assim, a dor é utilizada como forma de comunicação, como idioma, para esclarecer os valores. Na concepção de Christie, mostra-se necessário substituir o sistema penal por um sistema participativo no qual se busque a clarificação dos valores durante o processo e não com o

\footnotetext{
${ }^{55}$ HULSMAN, Louk. Penas perdidas: o sistema penal em questão, p. 95-96.

${ }^{56}$ HULSMAN, Louk. Penas perdidas: o sistema penal em questão, p. 62-63.

${ }^{57}$ HULSMAN, Louk. Penas perdidas: o sistema penal em questão, p. 102-103.

${ }^{58}$ HULSMAN, Louk. Penas perdidas: o sistema penal em questão, p. 140.

${ }^{59}$ ANITUA, Gabriel Ignacio. Histórias dos pensamentos criminológicos, p. 706.

${ }^{60}$ CARVALHO. Salo de. Antimanual de Criminologia, p. 250. Christie apresenta um balança da população carcerária mundial em: CHRISTIE, Nils. Elementos de geografia penal. Discursos Sediciosos. Crime, Direito e Sociedade. Rio de Janeiro: Revan, ano 7, nº 11,2002, p. 95-102.
} 
resultado. ${ }^{61}$

$\mathrm{O}$ autor registra que as teorias oficiais da pena variam conforme a visão que o Estado tem do homem. Em geral, o homem aparece como incentivado pela dor e pelo prazer, além de ser considerado como "filho" do Estado. Com efeito, o modelo punitivo se sustenta em imagens falsas e distorcidas do homem, da sociedade e das formas de controle da violência ${ }^{62}$. Trata-se de imagens simplistas que se orientam por dicotomias: correto ou incorreto, culpado ou inocente etc. A aplicação desse sistema de classificação binário influi tanto na avaliação de atos quanto de pessoas. ${ }^{63}$

Nesse quadro, o sistema penal tende a recortar a realidade de forma a enfocar apenas os aspectos mais convenientes a esse tipo de simplificação. Por conseguinte, fixa-se mais nos atos do que nas interações e mais nos sistemas biológicos ou de personalidade do que nos sistemas sociais. É, por isso, que esse sistema despreza qualquer análise da responsabilidade social e atribui relevância, unicamente, à responsabilidade pessoal. O resultado é que o ato, separado de seu contexto, é visto como um ponto no tempo e não como um processo, o que torna mais fácil classifica-lo como bom ou mau. ${ }^{64}$

A obra "Limites à dor" foi lançada em 1981, momento de colapso do ideal ressocializador da pena. Nela, Christie afirma que é preciso buscar alternativas ao castigo e não castigos alternativos ou justificativas alternativas ao castigo. Para o autor, a própria noção de crime só faz sentido entre pessoas que não se conhecem, o que é comum no contexto de anonimato da vida moderna, pois, entre pessoas conhecidas, o normal é buscar outras maneiras de evitar a violência e solucionar os problemas. ${ }^{65}$

O professor norueguês critica a "velha criminologia", que visa investigar as causas "biológicas" do crime e, assim, perde a perspectiva de que, na realidade, não existem crimes e sim conflitos. Critica também a "nova criminologia", que converte todos os conflitos interpessoais em meros conflitos de classes. Essas duas visões reforçam a expropriação dos conflitos em relação aos envolvidos. ${ }^{66}$

Segundo Christie, o Estado, por meio do sistema penal, realiza um controle formal que se expande na medida em que são reduzidos os mecanismos que realmente funcionam, isto é, os informais. Além disso, o controle social penal é conformado por um aparelho estatal burocrático e centralizado que, por carecer de

\footnotetext{
${ }^{61}$ CHRISTIE, Nils. Limites à dor: o papel da punição na política criminal. Trad. Gustavo Noronha de Ávila. Belo Horizonte: D’Plácido, 2016, p. 123-125.

${ }^{62}$ CARVALHO. Salo de. Antimanual de Criminologia, p. 250-251.

${ }^{63}$ CHRISTIE, Nils. Las imágenes del hombre en el derecho penal moderno. In: HULSMAN, Louk; CHRISTIE, Nils; MATHIESEN, Thomas; SCHEERER, Sebastian; STEINERT, Heinz; DE FOLTER, Rolf. Abolicionismo penal, p. 128.

${ }^{64}$ CHRISTIE, Nils. Las imágenes del hombre en el derecho penal moderno, p. 129. Cabe aqui a advertência feita por Karam, citando Christie: "o maior perigo da criminalidade nas sociedades contemporâneas não é o crime em si mesmo - e, aqui, acrescente-se, com ou sem adjetivos, organizado ou desorganizado. O maior perigo da criminalidade, nos tempos atuais, é sim o de que sua repressão acabe por nos conduzir ao totalitarismo”. (KARAM, Maria Lúcia. Pela abolição do sistema penal. PASSETTI, Edson (org.). Curso livre de abolicionismo penal, p. 102).

${ }^{65}$ ANITUA, Gabriel Ignacio. Histórias dos pensamentos criminológicos, p. 708.
} 
transparência, expropria o conflito das partes e da comunidade para geri-lo em seu próprio benefício. ${ }^{67}$

$\mathrm{O}$ autor aposta em formas alternativas de controle social não punitivas a fim de atender aos envolvidos no conflito originário, indo de encontro aos interesses dos "confiscadores" e, de certa forma, até de alguns "vitimadores", que podem estar dispostos a "abrir mão" do conflito. Os métodos participativos de solução de conflitos são importantes para condenado, vítima e sociedade, pois constituem uma oportunidade pedagógica de debater o ocorrido, expressar solidariedade e esclarecer as normas. ${ }^{68}$

Assim, nessa visão, os conflitos representam uma chance de participação, sendo que o sistema penal atual impõe a perda dessa chance de envolver os cidadãos em tarefas que têm importância imediata para eles. Observase, desse modo, que a crítica de Christie não se restringe ao sistema penal, mas se estende à democracia liberal e ao Estado do bem-estar, demandando maior participação da população. ${ }^{69}$

Christie concebe o conflito como algo de valor que pode ser "roubado" da mesma maneira que os bens materiais. Quando isso ocorre, a vítima perde em dobro, porquanto perde em face do ofensor e em face do Estado, ao ser excluída de qualquer participação em seu conflito. Se os conflitos são valiosos em si mesmos, motivo não há para negá-los, sob pena de serem perdidas oportunidades pedagógicas de esclarecimento de normas e de discussão contínua sobre o que representa a lei do país. ${ }^{70}$

A participação no conflito é mais importante do que a sua solução, sobretudo quando a solução significa a criação de outro conflito: a punição. Mais do que a mera admissão de reações diversas da punitiva, Christie nos provoca a compreender que nem sempre é necessário reagir. Os conflitos não precisam sempre ser resolvidos, mas devem ser reapropriados, isto é, os envolvidos devem reassumir o protagonismo e participar dos seus conflitos, em sua solução, saída ou manutenção. ${ }^{71}$

Nessa perspectiva, o castigo não faz sentido nem nos casos mais graves, devendo-se "deixar andar com a sua vergonha" os responsáveis por tais fatos, pois são mais importantes o diálogo e a reflexão comunitária do que o próprio castigo ${ }^{72}$. O autor rechaça totalmente as teorias utilitárias da pena que aceitam que as tragédias humanas sejam utilizadas para propósitos que estão fora do homem. Segundo Christie, é preciso deixar claro que a pena é

\footnotetext{
${ }^{66}$ CHRISTIE, Nils. Conflicts as property. Oxford: The British Journal of Criminology, v. 17, 1977, p. 05.

${ }^{67}$ ANITUA, Gabriel Ignacio. Histórias dos pensamentos criminológicos, p. 708.

${ }^{68}$ ANITUA, Gabriel Ignacio. Histórias dos pensamentos criminológicos, p. 706-707.

${ }^{69}$ ANITUA, Gabriel Ignacio. Histórias dos pensamentos criminológicos, p. 708.

${ }^{70}$ CHRISTIE, Nils. Limites à dor: o papel da punição na política criminal, p. 122.

${ }^{71}$ CHRISTIE, Nils. Limites à dor: o papel da punição na política criminal, p. 121-122; ANITUA, Gabriel Ignacio. Histórias dos pensamentos criminológicos, p. 709. Sobre esse tema, destaca-se a seguinte passagem: "Tendo trabalhado com conflitos a maior parte de minha vida, eu não sei exatamente o que é um conflito. E ainda mais: $\mathrm{O}$ que é uma solução? Seria quando as partes param de bater umas nas outras, param de gritar umas com as outras, fazem as pazes, começam a cooperar entre si, se tornam amigos: E o que é eficiência?" (CHRISTIE, Nils. Civilidade e Estado. In: PASSETI, Edison; SILVA, Roberto B. Dias da (org.). Conversações abolicionistas: uma crítica do sistema penal e da sociedade punitiva. São Paulo: IBCCRIM/PEPG em Ciências Sociais da PUC-SP, 1997, p. 254).

${ }^{72}$ ANITUA, Gabriel Ignacio. Histórias dos pensamentos criminológicos, p. 709.
} 
dor sem nenhum propósito e confiar que as pessoas envolvidas em um conflito, cientes disso, convertam o procedimento punitivo em diálogo ${ }^{73}$.

Portanto, a proposta de Christie é a adoção de um modelo de justiça participativa, o que poderia ser feito no âmbito do próprio direito civil ou seguindo o formato de práticas abolicionistas que, inclusive, já existem na atualidade, nada tendo de utópicas. Busca-se, assim, uma justiça horizontal que aproxime a comunidade e as partes envolvidas, a fim de formular regras móveis e específicas para cada situação, livres de soluções pré-definidas. Tratase de modelo baseado na participação e não na representação, uma vez que o protagonismo é assumido pelos próprios envolvidos no conflito e não por profissionais e especialistas. ${ }^{74}$

Contudo, no processo de justiça participativa, vítima e acusado não são deixados no limbo, sendo exigida uma discussão pública em que se examine a situação da vítima e todos os detalhes do ocorrido, analisando-se pormenorizadamente o que poderia ser feito pelo infrator, pela vizinhança local e pelo Estado. Esse processo é comparado pelo autor ao luto, pois não está focado em evitar a dor e sim em trabalha-la da melhor maneira possível. $^{75}$

\section{Thomas Mathiesen}

Desde a década de 1960, o sociólogo e filósofo norueguês Thomas Mathiesen, aliado a suas atividades como professor e pesquisador, dedica-se à militância em movimentos de desencarceramento da esquerda escandinava.

Na década de 1970, Mathiesen publicou "As políticas de abolição", obra na qual formula uma crítica ferrenha à pena de prisão, sustentando que: 1) a abolição do cárcere deve ser a meta de uma política criminal radical; 2) as penas alternativas ao cárcere são perigosas, pois podem se transformar, facilmente, em novas estruturas carcerárias com funções semelhantes ao cárcere, servindo, na verdade, a somar em lugar de substituir ${ }^{76} \mathrm{e}$ 3) para chegar à abolição, é necessária uma estratégia cuidadosamente trabalhada que combine reformas em curto

\footnotetext{
${ }^{73}$ CHRISTIE, Nils. Limites à dor: o papel da punição na política criminal, p. 131; CHRISTIE, Nils. Las imágenes del hombre en el derecho penal moderno, p. 138-140. Ressalva-se que, em escritos mais recentes, Christe admite algumas punições como inevitáveis, afastando-se parcialmente do defendido na obra "Limites à dor". Nesse sentido, vide: CHRISTIE, Nils. Uma razoável quantidade de crime. $1^{a}$ ed. Trad. André Nascimento. Rio Janeiro: Revan, 2011.

${ }^{74}$ CHRISTIE, Nils. Limites à dor: o papel da punição na política criminal, passim.

${ }^{75}$ CHRISTIE, Nils. Limites à dor: o papel da punição na política criminal, p. 126 e ss.

76 "Los distintos estudios de Estados Unidos, Canadá e Inglaterra demuestran que las alternativas a las cárceles no son válidas. Por el contrario, se convierten en 'adicionales'/'sumatorios' de las mismas, ya sea por el simple hecho de aumentar el número de personas bajo control social formal, o por sumar más que restar a todo el sistema de control formal. Las 'alternativas' planificadas tienden claramente a 'extender la red', como lo manifestara Stanley Cohen” (MATHIESEN, Thomas. La política del abolicionismo. In: HULSMAN, Louk; CHRISTIE, Nils; MATHIESEN, Thomas; SCHEERER, Sebastian; STEINERT, Heinz; DE FOLTER, Rolf. Abolicionismo penal, p. 115). Pavarini concorda com a crítica abolicionista às penas alternativas: PAVARINI, Massimo. El sistema de derecho penal entre abolicionismo y reduccionismo, p. 145.
} 
prazo e a abolição em longo prazo. ${ }^{77}$

No período em que foi publicada a referida obra, conforme registra Mathiesen, a abolição das prisões e do próprio sistema de controle criminal parecia uma meta possível, sendo que, na primeira parte da década de 1970, houve redução das taxas de encarceramento e a população carcerária diminuiu. Contudo, essa tendência foi revertida no final da década de 1970 e, durante a década de 1980, os números dispararam, tendo a população carcerária no mundo ocidental chegado a seu índice mais elevado na década de $19900^{78}$

Apesar disso, Mathiesen não vê a abolição do cárcere e da pena como um "sonho impossível". Afinal, a História contém relatos de grandes transformações que, pouco antes de ocorrerem, pareciam extremamente improváveis: a queda do Império Romano, a abolição da escravatura, a dissolução da União Soviética etc. O autor analisa, em específico, o processo de abolição da caça às bruxas na Espanha em 1614, afirmando que esse exemplo mostra que, em certas condições, todo um sistema penal, aparentemente sólido e duradouro, pode se desintegrar e desaparecer de modo muito rápido. ${ }^{79}$

Para Mathiesen, conquanto saibamos mais sobre as condições que sustentam os sistemas sociais, mostra-se necessário investigar o que favorece a sua mudança radical ${ }^{80}$. No caso da caça às bruxas na Espanha, observa que "uma mudança cultural importante aconteceu no interior da Inquisição e a atravessou", tendo havido "uma certa preparação cultural, um tipo de 'moderação cultural'. Assim, a abolição se deu "a despeito do fato de que no ambiente havia o que hoje poderíamos chamar de um pânico moral em relação às bruxas" ${ }^{81}$ Essa mudança cultural partiu da constatação de que a intensa caçada não fez com que as bruxas desaparecessem, mas o contrário.

Segundo Mathiesen, a mudança cultural foi condição suficiente para a abolição da caça às bruxas, mas não seria suficiente para a abolição do sistema pena atual. Isso porque esse último é muito mais dependente da opinião pública e dos meios de comunicação de massa. ${ }^{82}$ As informações que os meios de comunicação fornecem sobre o sistema penal e sobre o sistema carcerário é seletiva e distorcida, sendo que a crença que os indivíduos têm na televisão é semelhante a dos fiéis na Igreja. Esses meios dificultam a percepção de que, assim como a caça às bruxas, a prisão é totalmente irracional quando se considera os seus objetivos estabelecidos, não contribuindo em nada para a sociedade. ${ }^{83}$

Mathiesen critica as funções declaradas da pena, inclusive a de prevenção geral negativa. Para o autor, a influência da pena na decisão delitiva é, no mínimo, incerta, além de menos significativa do que a de fatores como

\footnotetext{
${ }^{77}$ MATHIESEN, Thomas. La política del abolicionismo, p. 109-110.

${ }^{78}$ MATHIESEN, Thomas. A caminho do século XXI - abolição, um sonho impossível? Verve. Revista do NU-SOL - Núcleo de Sociabilidade Libertária, n. 4, 2003, p. 81.

${ }^{79}$ MATHIESEN, Thomas. A caminho do século XXI, p. 82-83.

${ }^{80}$ MATHIESEN, Thomas. A caminho do século XXI, p. 84.

${ }^{81}$ MATHIESEN, Thomas. A caminho do século XXI, p. 88.

${ }^{82}$ MATHIESEN, Thomas. A caminho do século XXI, p. 89.

${ }^{83}$ MATHIESEN, Thomas. A caminho do século XXI, p. 101-102.
} 
as condições políticas, econômicas e sociais. Ademais, o efeito preventivo da prisão é muito modesto ou mesmo mínimo nos grupos populacionais em que se deseja que o efeito seja forte (grupos predispostos ao crime e infratores contumazes) e, talvez, mais forte nos grupos que, por outros motivos, já são obedientes à lei. Logo, a prevenção geral funciona, quando muito, para os que não necessitam da pena. ${ }^{84}$

Por outro lado, Mathiesen ressalta que a punição é a forma pela qual o Estado tenta comunicar uma mensagem, especialmente a grupos vulneráveis na sociedade. Dessa forma, a ineficiência preventiva da prisão constitui um problema de comunicação, vez que a mensagem que deveria ser transmitida é "filtrada e deturpada durante o processo e é confrontada com uma resposta cultural nos grupos que a desconsidera, acabando por neutralizá-la." ${ }^{85}$

Na visão do professor norueguês, a consciência geral da inutilidade da pena, a partir da destruição dos mitos relativos à prisão, poderia gerar mudanças nas pessoas e em seus representantes e provocar a reforma do sistema, cuja ênfase passaria a ser o apoio à vítima e ao transgressor. São algumas das formas de apoio à vítima por ele propostas: compensação financeira pelo Estado, sistema de seguro simplificado, abrigos protetivos, apoio econômico em casos de luto e centros de apoio. O autor afirma que "ao invés de aumentar a punição do transgressor de acordo com a gravidade da transgressão, o que é básico no sistema atual, eu proporia o aumento do apoio à vítima de acordo com a gravidade da transgressão". ${ }^{86}$

Para tanto, é necessário que profissionais da justiça, administradores do sistema penitenciário, intelectuais e pesquisadores quebrem o silêncio e denunciem a realidade do sistema prisional ${ }^{87}$. No caso dos administradores, esse silêncio é consequência da cooptação pelo sistema, bem como do sentimento de lealdade e da disciplina por ele imposta. Na posição de intelectual, Mathiesen pretende fazer a sua parte ao apresentar argumentos contrários à construção de novas prisões. ${ }^{88}$

A mudança da cultura é importante para que a guerra contra o crime se converta em guerra contra a pobreza e a falta de moradia, trabalho e educação, devendo também ser dada especial atenção à legalização das drogas. O desmantelamento das prisões liberaria recursos para investir nesses projetos. ${ }^{89}$ No entanto, tudo isso dependeria da criação de um "espaço público alternativo" apto a competir com o espaço público superficial dos

\footnotetext{
${ }^{84}$ MATHIESEN, Thomas. A caminho do século XXI, p. 91. Também em: MATHIESEN, Thomas. La política del abolicionismo, p. 120.

${ }^{85}$ MATHIESEN, Thomas. A caminho do século XXI, p. 92-93. Há, ainda, o profundo problema moral decorrente de se punir pessoas com o objetivo de prevenir outros de agir de forma semelhante, o qual também é reconhecido pelo próprio Ferrajoli.

${ }^{86}$ MATHIESEN, Thomas. A caminho do século XXI, p. 96.

${ }^{87}$ MATHIESEN, Thomas. A caminho do século XXI, p. 99.

${ }^{88 “} \mathrm{~A}$ irracionalidade verdadeira da prisão é um dos segredos melhor guardados em nossa sociedade. Se o segredo fosse revelado, destruiria as raízes do sistema atual e implicaria o começo de sua ruína" (MATHIESEN, Thomas. A caminho do século XXI, p. 98). ${ }^{89}$ MATHIESEN, Thomas. A caminho do século XXI, p. 97. Salienta-se que o autor admite que se mantenha a possibilidade excepcional de encarceramento, propondo a determinação de um número máximo de celas que possam ser ocupadas.
} 
meios de comunicação de massa, no qual pessoas reais poderiam debater essas ideias de forma organizada ${ }^{90}$.

Considerando que o sistema penal não se encaminha naturalmente para o seu fim, cabe às forças progressistas sair de seu imobilismo e parar de ceder terreno para que as forças reacionárias imponham ideias e práticas cada vez mais punitivas. Por isso, conforme a concepção desse estrategista do abolicionismo ${ }^{91}$, os críticos do sistema penal precisam se comprometer com reformas "negativas" e com a revolução.92

As reformas "negativas" são aquelas voltadas a reduzir a capacidade do sistema punitiva, seu sentido básico de sequestro que impede a participação e seu caráter repressivo e violador de direitos humanos. São, portanto, todas aquelas reformas que não obstaculizam a abolição (saídas temporárias, visitas, coabitação familiar, etc.), pois estão fundadas em suas próprias premissas e não nas mesmas premissas do sistema a ser abolido. As reformas negativas se contrapõem às positivas, que ampliam e reproduzem a estrutura carcerária. ${ }^{93}$

A estratégia formulada por Mathiesen estará sempre "inacabada", tendo em vista que a busca pela liberdade, igualdade e fraternidade não chega ao fim nem com a abolição das prisões. Daí a necessidade de uma "revolução permanente" e "sem limites". O novo modelo que emergiria com a abolição, assim como projetado por Christie, seria um modelo participativo. ${ }^{94}$

\section{Sebastian Scheerer}

Divulgador das ideias de Hulsman, Mathiesen e Christie na Alemanha desde a década de 1980, Sebastian Scheerer é professor de Criminologia na Universidade de Hamburgo. A sua perspectiva se diferencia por considerar utópica a ideia de uma sociedade sem sanções negativas, tendo em vista que a punição sempre existiu e sempre vai existir. Para o autor, a pena pode ser um mal necessário, mas não é necessariamente um mal, pois pode levar o indivíduo a refletir e criar-lhe novas oportunidades. ${ }^{95}$

Scheerer observa que, diferentemente da punição, o direito penal é um fenômeno relativamente recente. Antes do controle social estatal, as preocupações estavam centradas em reintegrar o desviante, reparar eventuais danos, restabelecer o status quo, pacificar e delimitar o conflito. A pena pública só nasceu juntamente com o

\footnotetext{
${ }^{90}$ MATHIESEN, Thomas. A caminho do século XXI, p. 108.

${ }^{91}$ Mathiesen é considerado o "estrategista do abolicionismo" porque as suas preocupações estavam centradas no desenvolvimento de uma teoria de ação política, isto é, em definir as estratégias políticas necessárias à abolição. Segundo De Folter, o abolicionismo de Mathiesen é mais amplo do que o de Hulsman porque pretende abolir não apenas o sistema penal, mas todo o sistema repressivo social próprio do capitalismo. (DE FOLTER, Rolf. Sobre la fundamentación metodológica del enfoque abolicionista del sistema de justicia penal, p. 70).

92 ANITUA, Gabriel Ignacio. Histórias dos pensamentos criminológicos, p. 703.

${ }^{93}$ ANITUA, Gabriel Ignacio. Histórias dos pensamentos criminológicos, p. 703; DE FOLTER, Rolf. Sobre la fundamentación metodológica del enfoque abolicionista del sistema de justicia penal, p. 71 .

${ }^{94}$ ANITUA, Gabriel Ignacio. Histórias dos pensamentos criminológicos, p. 703-704.

${ }^{5}$ SCHEERER, Sebastian. A punição deve existir! Deve existir direito penal? Trad. Raphael Boldt. Revista Brasileira de Ciências Criminais, no 117, v. 23, p. 364-365.
} 
Estado e, já há algum tempo, vem atuando de forma obsoleta. ${ }^{96}$

Segundo o autor, a ideia de que o direito penal é tão eterno quanto a punição remonta à obra "Dos delitos e das penas" de Beccaria, de 1764, sendo reproduzida até hoje. Contudo, a tese da universalidade da pena criminal é um engodo que visa torna-la necessária, justificada e racional. Se a prisão, a pena e o direito penal são invenções determinadas por um contexto social, não constituindo um complexo atemporal, não faz sentido preceitua-los como formas de controle universais. ${ }^{97}$

Assim, conquanto não exista sociedade sem normas e sanções, pode haver sociedade sem normas jurídicas e penas criminais. Isso porque os princípios da reciprocidade e da responsabilidade são universais, mas não os da retribuição e da culpabilidade. De fato, há vários exemplos de sociedades sem direito penal e sem penas criminais, mas não sem normas e sanções. É o caso das sociedades sem estruturas de dominação, anteriores ao aparecimento das classes sociais e da organização estatal..$^{98}$

Conforme observa o professor alemão, na década de 1970, a doutrina passou a enfatizar que o direito penal tem como função social a tutela de bens jurídicos individuais e coletivos e, com isso, esperava-se reduzi-lo ao mínimo necessário. No entanto, deu-se o contrário: o direito penal moderno se expandiu como nunca antes em sua história. ${ }^{99}$

Tal processo se deve ao fato de que os estudiosos, de forma geral, não têm dúvidas de que o Estado possui não só o direito, mas o dever e a capacidade de organizar a punição ${ }^{100}$. Já Scheerer demonstra ceticismo em relação ao Estado e questiona a possibilidade de se confiar no aparato estatal para determinar quais bens jurídicos devem ser protegidos e adequar a resposta punitiva ao autor do delito, sob o pretexto de dissuadi-lo ou neutralizá$\mathrm{lo}^{101}$. O autor assinala que o Estado já se mostrou capaz de cometer os crimes mais bárbaros, sendo que os rituais penais “reproduzem e ampliam, reiteradamente, a luxúria narcisista” estatal ${ }^{102}$ :

"Qualquer coisa seria melhor do que o monopólio penal na mão do Estado. O século XIX foi o século da esperança em relação ao Estado, o século XX foi o do fracasso e o dos crimes do Estado. Talvez o século XXI venha a se tornar o século de uma sociedade civil consciente, que confia em si e que regulará seus conflitos autonomamente e sem atrocidades". ${ }^{103}$

Diante disso, Scheerer sustenta que o direito penal deveria se reconverter, gradualmente, em um direito privado de mediação de conflitos. Afinal, o período do direito penal privado não foi necessariamente pior do que o

\footnotetext{
${ }^{96}$ SCHEERER, Sebastian. A punição deve existir! Deve existir direito penal?, p. 366-367.

${ }^{97}$ SCHEERER, Sebastian. A função social do direito penal. Trad. Raphael Boldt. Revista de Estudos Criminais, no 59, v. 14, 2015, p. 20.

98 SCHEERER, Sebastian. ¿La pena criminal como herencia cultural de la humanidad? Trad. Manuel Cancio Meliá. Revista Brasileira de Ciências Criminais, nº 57, v. 13, 2005, p. 101.

${ }^{99}$ SCHEERER, Sebastian. A função social do direito penal, p. 14; SCHEERER, Sebastian. A punição deve existir! Deve existir direito penal?, p. 368.

${ }^{100}$ SCHEERER, Sebastian. A punição deve existir! Deve existir direito penal?, p. 369.

${ }^{101}$ SCHEERER, Sebastian. A função social do direito penal, p.21.

${ }^{102}$ SCHEERER, Sebastian. A punição deve existir! Deve existir direito penal?, p. 370.
} 
do direito penal público ${ }^{104}$.

Em crítica à tradição de Von Liszt, Scheerer explica que não vê o direito penal como meio de autoproteção da sociedade, mas como instrumento de dominação sobre a comunidade ${ }^{105}$. Por isso, defende a desestatização da reação ao delito, em favor do desenvolvimento de uma sociedade de cidadãos autoconscientes que confiem mais nas suas próprias iniciativas, normas e responsabilidades do que na delegação ao Estado ${ }^{106}$.

No mesmo sentido que Mathiesen, o professor alemão ressalta que outras grandes transformações sociais da história da humanidade também eram consideradas utópicas ou irreais pelos experts de seu tempo até que o impensável aconteceu. Por outro lado, o pensamento abolicionista já conta com importantes vitórias ao longo do tempo, como é o caso da abolição dos castigos corporais, da tortura e da pena de morte em muitos lugares. ${ }^{107}$

Além disso, o autor critica as correntes do realismo de esquerda que advogam a proteção penal de novos bens, como é o caso dos movimentos ecologistas, feministas e antirracistas, bem como os que reivindicam a criminalização dos poderosos ${ }^{108}$. Para Scheerer, o abolicionismo importa numa "tomada de posição específica sobre os problemas do controle social que contém fundamentos teóricos 'negativos' desafiadores e estratégias políticas de transformação radical" ${ }^{109}$.

\section{A TÍTUlo DE SÍNTESE: AS RÉPLICAS ABOLICIONISTAS AO GARANTISMO DE FERRAJOLI}

Os abolicionistas são, comumente, acusados de assumirem uma postura utópica e ingênua. Todavia, como reconhece o próprio Ferrajoli, o direito penal mínimo e garantista não é menos utópico, sendo a sua concretização inevitavelmente parcial e imperfeita. ${ }^{110}$

Em suas propostas, o abolicionismo busca inspiração em estruturas existentes em sociedades tradicionais que ainda subsistem na modernidade, embora ignoradas pelo discurso punitivo oficial ${ }^{111}$. Com isso, propõe

\footnotetext{
${ }^{103}$ SCHEERER, Sebastian. A punição deve existir! Deve existir direito penal?, p. 371.

${ }^{104}$ SCHEERER, Sebastian. A função social do direito penal, p. 21-22; SCHEERER, Sebastian. A punição deve existir! Deve existir direito penal?, p. 370-371.

${ }^{105}$ SCHEERER, Sebastian. ¿La pena criminal como herencia cultural de la humanidad?, p. 102. Nesse sentido, o autor critica, fortemente, o direito penal das drogas. Cf. SCHEERER, Sebastian. Economia dirigida e perspectivas da política de drogas. Discursos Sediciosos: crime, direito e sociedade, nº 14, 2004, p. 105-115.

${ }^{106}$ SCHEERER, Sebastian. ¿La pena criminal como herencia cultural de la humanidad?, p. 109.

${ }^{107}$ SCHEERER, Sebastian. Hacia el abolicionismo, p. 17-19.

${ }^{108}$ SCHEERER, Sebastian. Hacia el abolicionismo, p. 33.

${ }^{109}$ ANITUA, Gabriel Ignacio. Histórias dos pensamentos criminológicos, p. 712-713.

110 "Quizá la verdadera utopía no es hoy la alternativa al derecho penal, sino el derecho penal mismo y sus garantías; no el abolicionismo, sino el garantismo, de hecho inevitablemente parcial e imperfecto.” (FERRAJOLI, Luigi. Derecho y razón, p. 342).

${ }^{111}$ CELIS, Jacqueline Bernat de Celis; HULSMAN, Louk. Conversas com um abolicionista do sistema penal, p. 38. No mesmo sentido: PASSETTI, Edson. A atualidade do abolicionismo penal, p. 19.
} 
desmistificar a pretensa superioridade das sociedades industriais sobre as tradicionais ou menos industrializadas ${ }^{112}$.

De fato, o aparato burocratizado, profissionalizado e formalizado que expropria os conflitos dos partícipes diretos das situações problemáticas é herança recente do Estado moderno e nada garante que seja a forma mais evoluída e desenvolvida de controle social que já existiu. No entanto, na visão de autores como Ferrajoli, esse processo de formalização representou um avanço civilizatório, na medida em que atendeu demandas de proteção das liberdades individuais e limitação do poder punitivo do Estado. ${ }^{113}$

Ocorre que os fenômenos da seletividade penal e das cifras negras denunciam a incapacidade do sistema penal em desempenhar adequadamente suas funções declaradas. Além disso, a máquina penal apresenta um índice extremamente elevado de arbitrariedade que causa incessantemente sofrimento gratuito e inútil. Por consequência, os abolicionistas têm razão em afirmar que o sistema penal é um problema social em si mesmo e não, certamente, um meio orientado a resolver problemas sociais. ${ }^{114}$

Nessa linha, os abolicionistas destacam que o sistema penal não impede que pessoas acusadas da prática de crimes continuem a sofrer violências arbitrárias, como demonstram os exemplos atuais de linchamentos ${ }^{115}$. Nota-se que, em geral, esses atos de vingança privada são cometidos contra grupos que já sofrem com a hipercriminalização: jovens pobres, negros, usuários de drogas e acusados de crimes contra o patrimônio. Por outro lado, não se verifica esse tipo de reação informal contra grupos que contam mais facilmente com a impunidade, como é o caso da criminalidade de colarinho branco ${ }^{116}$.

Por certo, Ferrajoli presume que houve diminuição da violência na passagem da pena privada para a pena pública. Isso porque a pena pública, mesmo quando brutal, não é vista por ele como "vingança de sangue", mas tão somente a pena privada ${ }^{117}$. Diferentemente do professor italiano, Larrauri entende que nem toda pena privada é vingança de sangue, sendo certo também que a pena pública não é a única forma de evitar a violência arbitrária. Para a autora, um modelo de justiça restaurativa, por exemplo, submeteria o poder à regulação jurídica e produziria uma resposta apta a evitar arbitrariedades. Assim, os abolicionistas não negam que se deve reagir em alguns casos, mas propõem a diversificação de respostas que não a punitiva. ${ }^{118}$

Ademais, não faz sentido apelar à sana punitiva das vítimas, seus familiares ou da sociedade para justificar

\footnotetext{
${ }^{112}$ CHRISTIE, Nils. Limites à dor: o papel da punição na política criminal, p. 121.

${ }^{113}$ PAVARINI, Massimo. El sistema de derecho penal entre abolicionismo y reduccionismo, p. 149-150.

${ }^{114}$ PAVARINI, Massimo. El sistema de derecho penal entre abolicionismo y reduccionismo, p. 148-149.

${ }^{115}$ Veja-se, por exemplo, o caso do jovem que, acusado de tentar roubar uma bicicleta, foi torturado e teve tatuada em sua testa a frase "sou ladrão e vacilão": http://noticias.r7.com/sao-paulo/jovem-acusado-de-roubo-e-torturado-e-tatuado-sou-ladrao-evacilao-1 1062017. Acesso em 27/06/2017, às 15:30.

${ }^{116}$ LARRAURI, Elena Pijoan. Criminología crítica: abolicionismo y garantismo. Revista de la Asociación de Ciencias Penales de Costa Rica, $n^{\circ} 17$, v. 12, 2000, p. 17.

${ }^{117}$ LARRAURI, Elena Pijoan. Criminología crítica: abolicionismo y garantismo, p. 13.
} 
a punição. Afinal, não seria possível legitimar a pena de morte com base no argumento de que, se o Estado não o fizer, os particulares tirarão a vida do ofensor. Larrauri registra, a partir de Steigert, que os linchamentos nos Estados Unidos são mais comuns nos Estados em que mais se executa a pena de morte. Ora, será que as demandas punitivas da população não são moldadas pelo próprio sistema? Será que as pessoas não querem prender porque o sistema promete prender? ${ }^{119}$

Dessa forma, os discursos de legitimação do sistema penal presumem o desejo por vingança sem uma reflexão sobre em que tipo de sociedade e sob que circunstâncias esse desejo surge e se intensifica. Há estudos que indicam, por exemplo, que a demanda por vingança parte mais de quem não foi afetado pelo crime do que da própria vítima, que pode preferir, em muitos casos, obter algum tipo compensação ou simplesmente esquecer e superar o ocorrido. ${ }^{120}$

O risco de "perda de garantias" de que fala Ferrajoli pode ser alegado contra qualquer proposta de descriminalização. Essa objeção é levantada, inclusive, contra o uso do direito administrativo sancionador no lugar do direito penal e a criação de um direito de intervenção como proposto por Hassemer. Entretanto, se o importante para Ferrajoli é respeitar a forma jurídica da pena, essa forma jurídica não precisa ser dada necessariamente pelo direito penal ${ }^{121}$. Em verdade, nem todas as perspectivas abolicionistas prescindem da intervenção do Direito como mecanismo regulador. Christie, por exemplo, entende como necessária a manutenção do Estado para evitar abusos na reação aos conflitos ${ }^{122}$.

Em relação à função da pena de prevenção geral, Pavarini assevera que bibliotecas inteiras estão repletas de investigaçoes empíricas e reflexões teórico-científicas que negam a possibilidade de alcançar tal fim ${ }^{123}$. De maneira mais comedida, Larrauri afirma que ainda não foi possível comprovar empiricamente os efeitos preventivos da pena ${ }^{124}$. De fato, o mito da prevenção geral se baseia em uma imagem simplificada do homem que não condiz sempre com a realidade, qual seja, a do homus economicus racional e calculista, cujos atos não são influenciados por um conjunto complexo de fatores (ambientais, químicos, psíquicos, emotivos, morais, religiosos, sociais etc.) para além da análise futurista de custo-benefício.

Aliás, "da premissa de que o comportamento humano é modificável por incentivos, não se deriva como consequência inelidível que o castigo seja a medida mais eficaz frente a todos os comportamentos que

\footnotetext{
${ }^{118}$ LARRAURI, Elena Pijoan. Criminología crítica: abolicionismo y garantismo, p. 16.

${ }^{119}$ LARRAURI, Elena Pijoan. Criminología crítica: abolicionismo y garantismo, p. 14-15.

${ }^{120}$ LARRAURI, Elena Pijoan. Criminología crítica: abolicionismo y garantismo, p. 15. Para uma crítica à resposta abolicionista à questão da vingança privada levantada por Ferrajoli, Cf.: PAVARINI, Massimo. El sistema de derecho penal entre abolicionismo y reduccionismo, p. 146.

${ }^{121}$ LARRAURI, Elena Pijoan. Criminología crítica: abolicionismo y garantismo, p. 07-09.

${ }^{122}$ CHRISTIE, Nils. Limites à dor: o papel da punição na política criminal, p. 147.

${ }^{123}$ PAVARINI, Massimo. El sistema de derecho penal entre abolicionismo y reduccionismo, p. 148.

${ }^{124}$ LARRAURI, Elena Pijoan. Criminología crítica: abolicionismo y garantismo, p. 17.
} 
pretendemos evitar"125 (tradução nossa). Há que se reconhecer que a efetividade da pena nesse quesito é afetada, por exemplo, pelo fato de que os sujeitos tendem, por meio de mecanismos psicológicos, a neutralizar o discurso proibitivo e a minimizar a gravidade de determinados atos. Isso ocorre, especialmente, quando o grupo social em que estão inseridos lhes oferece suporte ao não censurar ou reprovar tais comportamentos.

Desse modo, embora o abolicionismo não pretenda apresentar um modelo perfeito e acabado para a superação do sistema penal, seus defensores levantam pontos que fragilizam a legitimação da pena criminal a partir do ideal de prevenção de crimes e de castigos arbitrários. Diante disso, pode-se concluir, com Pavarini, que não é necessário ser abolicionista para fazer um bom uso do abolicionismo ${ }^{126}$, isto é, para admitir a necessidade de repensar crítica e profundamente as estruturas de controle social do Estado.

\title{
GARANTISTS VS. ABOLITIONISTS: FERRAJOLI'S CRITICS TO CRIMINAL ABOLITIONISM AND THE ABOLITIONIST'S REPLIES TO CRIMINAL GUARANTEEISM
}

\begin{abstract}
Although there is no incompatibility between guaranteeism and abolitionism, Ferrajoli's criminal guaranteeism moves away from the abolitionist thinking as it assumes the possibility of recovering the legitimacy of the criminal system. This article analyzes Ferrajoli's criticisms against the proposals for punitive model abolishment, especially regarding the need for criminal control to minimize formal and informal violences. In order to oppose this logic, the visions of four exponents of penal abolitionism are presented: Hulsman, Christie, Mathiesen and Scheerer. The conclusions provide a synthesis of the abolitionist responses to the defense made by Ferrajoli for the maintenance of State's criminal reaction.
\end{abstract}

Keywords: Guaranteeism; Abolitionism; Ferrajoli; Hulsman; Criminal System.

\section{BIBLIOGRAFIA}

ANDRADE, Vera Regina Pereira de. Minimalismos, abolicionismos e eficienticismo: a crise do sistema penal entre a deslegitimação e a expansão. Revista Sequência. Florianópolis, nº 52, jul., 2006, p. 163-182.

ANITUA, Gabriel Ignacio. Histórias dos pensamentos criminológicos. Trad. Sérgio Lamarão. $1^{\text {a }}$ ed. Rio de Janeiro, Revan, 2008.

\footnotetext{
${ }^{125}$ No original: "( ... de la premisa de que el comportamiento humano es modificable por incentivos, no se deriva como consecuencia ineludible que el castigo se ala medida más eficaz frente a todos los comportamientos que pretendemos evitar" (LARRAURI, Elena Pijoan. Criminología crítica: abolicionismo y garantismo, p. 20).

${ }^{126}$ PAVARINI, Massimo. El sistema de derecho penal entre abolicionismo y reduccionismo, p. 157.
} 
BARATTA, Alessandro. Criminologia crítica e crítica ao direito penal. Rio de Janeiro: Revan, 2002.

CARVALHO. Salo de. Antimanual de Criminologia. 5a ed. São Paulo: Saraiva, 2013.

CELIS, Jacqueline Bernat de Celis; HULSMAN, Louk. Conversas com um abolicionista do sistema penal. In: HULSMAN, Louk. Penas perdidas: o sistema penal em questão. Trad. Maria Lúcia Karam. Rio de Janeiro: Luam Editora, 1993, p. 17-50.

CHRISTIE, Nils. Civilidade e Estado. In: PASSETI, Edison; SILVA, Roberto B. Dias da (org.). Conversações abolicionistas: uma crítica do sistema penal e da sociedade punitiva. São Paulo: IBCCRIM/PEPG em Ciências Sociais da PUC-SP, 1997, p. 241-257.

CHRISTIE, Nils. Conflicts as property. Oxford: The British Journal of Criminology, v. 17, 1977.

CHRISTIE, Nils. Elementos de geografia penal. Discursos Sediciosos. Crime, Direito e Sociedade. Rio de Janeiro: Revan, ano 7, no 11, 2002, p. 95-102.

CHRISTIE, Nils. Las imágenes del hombre en el derecho penal moderno. In: HULSMAN, Louk; CHRISTIE, Nils; MATHIESEN, Thomas; SCHEERER, Sebastian; STEINERT, Heinz; DE FOLTER, Rolf. Abolicionismo penal. Trad. Mariano Alberto Ciafardini y Mirta Lilián Bondanza. Buenos Aires: Ediar Sociedad Anónima, 1989, p. 127-141.

CHRISTIE, Nils. Limites à dor: o papel da punição na política criminal. Trad. Gustavo Noronha de Ávila. Belo Horizonte: D’Plácido, 2016.

CHRISTIE, Nils. Uma razoável quantidade de crime. 1ª ed. Trad. André Nascimento. Rio Janeiro: Revan, 2011.

DAVIS, Angela Y. Are prisons obsolete? New York: Seven Stories Press, 2003.

DE FOLTER, Rolf. Sobre la fundamentación metodológica del enfoque abolicionista del sistema de justicia penal. Una comparación de las ideas de Hulsman, Mathiesen y Foucalt. In: HULSMAN, Louk; CHRISTIE, Nils; MATHIESEN, Thomas; SCHEERER, Sebastian; STEINERT, Heinz; DE FOLTER, Rolf. Abolicionismo penal. Trad. Mariano Alberto Ciafardini y Mirta Lilián Bondanza. Buenos Aires: Ediar Sociedad Anónima, 1989, p. 5785

FERRAJOLI, Luigi. Derecho y razón. Teoría del garantismo penal. Trad. Andrés Ibáñez, Alfonso Ruiz Miguel, Juan Carlos Bayón Mohino, Juan Terradillos Basoco e Rocío Cantarero Bandrés. 5a ed. Madrid: Trotta, 2001.

HASSEMER, Winfried. Contra el abolicionismo: acerca de por qué no se debería suprimir el derecho penal, Revista de Derecho Penal, n. 2, 2007, p. 709-729.

HULSMAN, Louk. Alternativas à justiça criminal. In: PASSETTI, Edson (org.). Curso livre de abolicionismo penal. $2^{a}$ ed. Rio de Janeiro: Revan, 2012, p. 35-68.

HULSMAN, Louk. La criminología crítica y el concepto de delito. In: HULSMAN, Louk; CHRISTIE, Nils; MATHIESEN, Thomas; SCHEERER, Sebastian; STEINERT, Heinz; DE FOLTER, Rolf. Abolicionismo penal. Trad. Mariano Alberto Ciafardini y Mirta Lilián Bondanza. Buenos Aires: Ediar Sociedad Anónima, 1989, p. 87107. 
HULSMAN, Louk. Penas perdidas: o sistema penal em questão. Trad. Maria Lúcia Karam. Rio de Janeiro: Luam Editora, 1993.

KARAM, Maria Lúcia. Pela abolição do sistema penal. PASSETTI, Edson (org.). Curso livre de abolicionismo penal. 2a ed. Rio de Janeiro: Revan, 2012, p. 69-107.

LARRAURI, Elena Pijoan. Criminología crítica: abolicionismo y garantismo. Revista de la Asociación de Ciencias Penales de Costa Rica, no 17, v. 12, 2000, p. 07-27.

MATHIESEN, Thomas. A caminho do século XXI - abolição, um sonho impossível? Verve. Revista do NUSOL - Núcleo de Sociabilidade Libertária, n. 4, 2003, p. 80-111.

MATHIESEN, Thomas. La política del abolicionismo. In: HULSMAN, Louk; CHRISTIE, Nils; MATHIESEN, Thomas; SCHEERER, Sebastian; STEINERT, Heinz; DE FOLTER, Rolf. Abolicionismo penal. Trad. Mariano Alberto Ciafardini y Mirta Lilián Bondanza. Buenos Aires: Ediar Sociedad Anónima, 1989, p. 109-125.

PASSETTI, Edson. A atualidade do abolicionismo penal. In: PASSETTI, Edson (org.). Curso livre de abolicionismo penal. $2^{a}$ ed. Rio de Janeiro: Revan, 2012, p. 13-33.

PAVARINI, Massimo. El sistema de derecho penal entre abolicionismo y reduccionismo. Trad.J. L. Domínguez y R. Bergalli. Poder y control. Revista hispano-latinoamericana de disciplinas sobre el control social, no 1, 1987, p. 141-157.

PIRES, Ariosvaldo de Campos; SALES, Sheila Jorge Selim de. Alguns movimentos político-criminais da atualidade. Revista Brasileira de Ciências Criminais, no 42, ano 11, jan.-mar., 2003, p. 295-306

SCHEERER, Sebastian. ¿̇La pena criminal como herencia cultural de la humanidad? Trad. Manuel Cancio Meliá. Revista Brasileira de Ciências Criminais, no 57, v. 13, 2005, p. 106-119.

SCHEERER, Sebastian. A função social do direito penal. Trad. Raphael Boldt. Revista de Estudos Criminais, $n^{\circ}$ 59 , v. 14, 2015, p. 09-23.

SCHEERER, Sebastian. A punição deve existir! Deve existir direito penal? Trad. Raphael Boldt. Revista Brasileira de Ciências Criminais, no 117, v. 23, p. 363-372.

SCHEERER, Sebastian. Economia dirigida e perspectivas da política de drogas. Discursos Sediciosos: crime, direito e sociedade, $\mathrm{n}^{\circ}$ 14, 2004, p. 105-115.

SCHEERER, Sebastian. Hacia el abolicionismo. In: HULSMAN, Louk; CHRISTIE, Nils; MATHIESEN, Thomas; SCHEERER, Sebastian; STEINERT, Heinz; DE FOLTER, Rolf. Abolicionismo penal. Trad. Mariano Alberto Ciafardini y Mirta Lilián Bondanza. Buenos Aires: Ediar Sociedad Anónima, 1989, p. 15-34.

ZAFFARONI, Eugenio Raúl. Em busca das penas perdidas. A perda de legitimidade do sistema penal. Rio de Janeiro: Revan, 1991.

Trabalho enviado em 17 de julho de 2017.

Aceito em 28 de outubro de 2017. 